\title{
ANALISIS LIKUIDITAS, PROFITABILITAS, DAN RETURN SAHAM PADA PERUSAHAAN MANUFAKTUR DI INDONESIA
}

\author{
Ijratul Fajri) , Aminar Sutra Dewi ${ }^{2)}$ \\ ${ }^{1,2)}$ Sekolah Tinggi Ilmu Ekonomi KBP \\ Email1): ijratulfajry@gmail.com \\ Email $^{2)}$ aminarsutradewi@akbpstie.ac.id
}

\begin{abstract}
To invest in the capital market, investors must know that in addition to receiving profits, they will also suffer losses. One of the motives of inventors to invest is to get a maximum rate of return with certain risk or obtain a certain rate of return on minimal risk. This study aims to examine the effect of liquidity and profitability on stock returns. The population is a manufacturing company which are listed in Indonesia Stock Exchange in 2013-2017 periods. The sampling technique uses a purposive sampling method with predetermined criteria and obtained a sample of 34 companies with 170 observations. The data of the financial statement of the companies has been obtained from the official website of IDX. The analytical method used is regression analysis of panel data with the help of application E-Views 8. Panel data regression can be estimated using three models, namely Common Effect Model (CEM), Fixed Effect Model (FEM), and Random Effect Model (REM). To get the best model, a further test was used, namely the Chow Test and Hausman Test. From the results of the estimation model, it is found that REM is the best model in this study. Furthermore, the results of the study show that liquidity has a positive and not significant effect on stock returns, while profitability has a positive and significant effect on stock returns.
\end{abstract}

Keywords: Liquidity, Profitability, Stock Returns

\section{PENDAHULUAN}

Mendapatkan return (tingkat pengembalian) yang maksimal pada risiko yang minimal merupakan tujuan investor dalam berinvestasi. Selain itu, investor tentunya juga akan memilih saham perusahaan mana yang akan memberikan return tinggi. Dalam jual beli saham, keuntungan yang didapat dari investasi saham disebut dengan capital gain (Dewi, 2016).

Hasil yang didapatkan dari investasi disebut return, bisa berupa return realisasi yang sudah terjadi atau return ekspektasi yang belum terjadi namun diharapkan akan terjadi dimasa datang. Selisih antara return sesungguhnya terjadi dengan return ekspektasi disebut dengan return tidak normal (abnormal return) (Rusliati dan Farida, 2010).

Adapun return saham bersifat positif, dimana investor akan mendapatkan keuntungan. Sedangkan return saham yang bersifat negatif akan mengalami kerugian. Dengan demikian, dalam berinvestasi tentunya investor selalu berusaha untuk mendapatkan keuntungan atau return saham yang bersifat positif (Tarmizi, Soedarsa, Indrayenti, dan Andrianto, 2018).

Kemampuan perusahaan dalam menghasilkan keuntungan dapat diukur dengan return saham. Return saham dimasa depan dapat diprediksi dengan 
menggunakan return saham ditahun sebelumnya. Oleh karena itu, dalam berinvestasi investor harus melakukan penelitian terlebih dulu terhadap sahamsaham yang dipilihnya. Hal ini dilakukan agar investor dapat menentukan apakah saham tersebut sesuai dengan tingkat return yang diharapkan atau tidak(Tarmizi, Soedarsa, Indrayenti, dan Andrianto, 2018).

Likuiditas merupakan kemampuan suatu aktiva atau instrumen untuk berubah bentuk menjadi kas atau setara kas (Wira, 2012). Kinerja jangka pendek perusahaan akan semakin baik jika semakin besar likuiditas suatu perusahaan tersebut, sehingga minat para investor untuk berinvestasi pada perusahaan tersebut semakin tinggi. Dengan demikian, akan menghasilkan peningkatan terhadap harga saham dan return saham pun naik (Tarmizi, Soedarsa, Indrayenti, dan Andrianto, 2018).

Menurut Munawir (2005) Current ratio (CR) ialah rasio likuiditas dalam menganalisis tingkat likuid suatu perusahaan, yaitu dengan membandingkan antara aktiva lancar dengan utang lancar. bagi investor di pasar modal, jika current ratio tinggi, maka perusahaan go public tidak akan memiliki kendala pada kewajiban jangka pendek. Oleh karena itu, informasi mengenai kinerja perusahaan adalah dengan memiliki current ratio yang tinggi (Kurniawan dan Ghasarma, 2009).

Profitabilitas ialah ukuran seberapa besar keuntungan yang bisa diterima dari modal saham, tingkat penjualan, dan kekayaan (asset) yang dimiliki perusahaan. Keberhasilan suatu perusahaan dalam memperoleh laba dapat dilihat dari meningkatnya profitabilitas perusahaan tersebut. Sehingga kinerja keuangan perusahaan juga akan semakin membaik (Sutriani, 2014).

Rasio profitabilitas ialah rasio yang digunakan untuk menilai kemapuan sebuah perusahaan didalam mendapatkan keuntungan atau laba. Rasio ini juga memperlihatkan tingkat efektivitas manajemen perusahaan yang bisa dilihat dari laba yang dihasilkan melalui penjualan dan pendapatan investasi (Tarmizi, Soedarsa, Indrayenti, dan Andrianto, 2018). Salah satu indikator yang digunakan pada profitabilitas adalah Return On Asset (ROA). Perusahaan akan semakin efektif menggunakan aktiva untuk menghasilkan Earning After Tax (laba bersih sesudah pajak) jika Return On Asset (ROA) semakin tinggi (Sutriani, 2014).

Pengaruh likuiditas dan profitabilitas terhadap return saham telah dilakukan kajian secara empiris oleh beberapa penelitian terdahulu. Pada penelitian Tarmizi, Soedarsa, Indrayenti, dan Andrianto (2018) menemukan adanya hubungan positif yang signifikan antara Likuiditas dan Return Saham. Parwati dan Sudiartha (2016) juga menemukan bahwa Likuditas berpengaruh positif terhadap Return Saham. Selain itu, penelitian terdahulu yang dilakukan oleh Farkhan dan Ika (2012) menunjukkan bahwa Profitabilitas berpengaruh positif dan signifikan terhadap Return Saham.

Perbedaan dari penelitian sebelumnya yaitu, dari segi metode (method) dengan menggunakan regresi data panel yang tidak dilakukan pada penelitian sebelumnya. Alasan digunakannya analisis regresi data panel adalah, karena data yang digunakan berbentuk panel berupa gabungan time series dan cross section dimana penelitian ini bisa dilakukan lebih dari satu tahun dan lebih dari satu perusahaan.

Likuiditas adalah bagaimana perusahaan mampu memenuhi kewajiban jangka pendeknya. Tingginya likuiditas suatu perusahaan, semakin baik pula 
kinerja jangka pendek perusahaan itu. Sehingga para investor akan semakin percaya terhadap perusahaan tersebut, dan hal ini akan berimbas pada peningkatan harga saham serta mengakibatkan naiknya return saham (Tarmizi, Soedarsa, Indrayenti, dan Andrianto, 2018). Kemampuan perusahaan untuk membayar utang lancar dilihat dari likuiditas perusahaan tersebut dengan menggunakan aktiva lancar yan $g$ dimiliki. Jika likuiditas tinggi, berarti perusahaan mampu memenuhi kewajiban jangka pendeknya (Sutriani, 2014).

Pada penelitian Parwati dan Sudiartha (2016) menemukan bahwa Likuditas berpengaruh positif terhadap Return Saham. Perusahaan yang mampu memenuhi kewajiban jangka pendeknya, menunjukan bahwa perusahaan tersebut meiliki current ratio yang tinggi. Meningkatnya kredibilitas suatu perusahaan dimata investor dengan tingkat likuid yang tinggi, maka akan mengakibatkan return saham menigkat pada perusahaan tersebut.

Selain itu, penelitian Surya, Agusti dan Asnel (2010) juga menunjukkan bahwa Likuditas berpengaruh positif terhadap Return Saham. Karena apabila current ratio meningkat, maka ada kecendrungan akan diiringi dengan peningkatan return saham. Adapun hipotesis yang dirumuskan pada pengamatan ini yaitu :

\section{$H_{1}$ : Likuiditas berpengaruh positif dan signifikan terhadap Return Saham}

Kinerja perusahaan dalam menghasilkan keuntungan ditunjukan pada profitabilitas perusahaan tersebut. Investor akan tertarik untuk menanamkan modalnya jika kinerja perusahaan tersebut tinggi dalam memperoleh laba. Karena jika permintaan saham meningkat, harga sahampun akan meningkat dan berdampak baik padea return saham perusahaan tersebut (Tarmizi, Soedarsa, Indrayenti, dan Andrianto, 2018).

Profitabilitas adalah ukuran bagaimana suatu perusahaan mampu dalam memperoleh laba dari modal saham, tingkat penjualan, dan aset yang dimiliki perusahaan. Karena kinerja perusahaan yang baik ditunjukan dengan tingkat profit yang tinggi dalam memperoleh keuntungan atau laba. Jadi, semakin meningkatnya ROA maka dividen yang diterima oleh pemegang saham akan meningkat (Sutriani, 2014).

Penelitan yang dilakukan oleh Farkhan dan Ika (2012) yang menunjukkan bahwa Profitabilitas yang diukur dengan ROA (Return On Asset) berpengaruh positif dan signifikan terhadap Return Saham. Penelitiannya mengemukakan bahwa tolak ukur pada kinerja perusahaan, Return On Assets (ROA) masih dipakai oleh investor untuk memprediksi total return saham. Karena Return On Assets (ROA) yang semakin besar mengakibatkan return saham juga akan naik.

Selain itu penelitian Fitriana, Andini dan Oemar (2016) juga menunjukan profitabilitas berpengaruh positif terhadap return saham. Karena nilai profit yang tinggi dimiliki oleh perusahaan akan menghasilkan keuntungan yang lebih tinggi dalam mengoptimalkan modalnya yang dikelola oleh manajer perusahaan. Perusahaan yang mampu menghasilkan laba yang optimal baahkan tinggi, akan memberikan sinyal yang positif bagi investor pada perusahaan serta memberikan pengaruh positif pada return saham perusahaan tersebut. Adapun hipotesis yang dirumuskan pada pengamatan ini yaitu :

$\mathrm{H}_{2}$ : Profitabilitas berpengaruh positif dan signifikan terhadap Return Saham

\section{METODE PENELITIAN}




\section{Data dan Sampel}

Penelitian ini dilakukan pada perusahaan manufaktur yang terdaftar di Bursa Efek Indonesia. Alasan pemilihan obyek ini adalah dalam pemilihan sampel tidak terdapat kendala kekurangan data, dan titik informasi yang pasti mengenai industri yang telah go public.

Dalam penelitian ini, Annual Report dan Summary digunakan sebagai sumber data utama. Jenis data yang didapatkan dari Annual Report dan Summary berupa data kuantitatif. Data kuantitatif yang digunakan seperti laporan laba rugi, laporan ekuitas, laporan neraca. Teknik pengumpulan data yang digunakan dalah dokumentasi.

Populasi pada pengamatan ini yaitu perusahaan manufaktur yang terdaftar pada Bursa Efek Indonesia di akhir periode observasi, yaitu 2017 sebanyak 147 perusahaan. Metode purposive sampling merupakan metode penarikan sampel dengan penilaian yang berdasarkan pada kriteria sesuai dengan objek maupun subjek yang untuk diamati pada penelitian ini. Adapun kriteria untuk pengambilan sampel sebagai berikut:

1. Perusahaan manufaktur yang terdaftar di Bursa Efek Indonesia diakhir periode observasi, yaitu tahun 2017.

2. Perusahaan manufaktur yang terdaftar secara berturut-turut pada Bursa Efek Indonesia selama periode observasi (2013-2017).

3. Perusahaan manufakur memiliki data keuangan sesuai dengan variabel yang akan diuji yaitu Return Saham, Likuditas, dan Profitabilitas.

4. Perusahaan manufaktur yang memiliki variabel dengan data yang logis (tidak ekstrim).

Berdasarkan kriteria-kriteria tersebut, maka diperoleh sampel pada Tabel berikut:

Tabel 1

Tabulasi Pengambilan Sampel Menggunakan Purposive Sampling

\begin{tabular}{clc}
\hline No & \multicolumn{1}{c}{ Kiteria } & Jumlah \\
\hline 1 & $\begin{array}{l}\text { Perusahaan manufakur yang terdaftar di BEI pada akhir periode } \\
\text { observasi, yaitu 2017. }\end{array}$ & 147 \\
2 & $\begin{array}{l}\text { Perusahaan manufakur yang tidak terdaftar berturut-turut selama } \\
\text { periode observasi (2013-2017). } \\
\text { Perusahaan manufakur yang tidak memiliki data keuangan sesuai } \\
\text { dengan variabel yang akan diuji yaitu Return Saham, Likuditas, } \\
\text { dan Profitabilitas. }\end{array}$ & (20) \\
4 & $\begin{array}{l}\text { Perusahaan manufaktur yang memiliki variabel dengan data tidak } \\
\text { logis (ekstrim). }\end{array}$ & (57) \\
\hline & \multicolumn{1}{c}{ Jumlah Sampel Akhir } & 170 \\
\hline
\end{tabular}

Sumber : Diolah Peneliti, 2018

\section{Definisi Operasional Variabel}

Dalam penelitian ini terdiri dari dua macam variabel yaitu variabel independent dan dependent. Variabel independent yaitu Likuiditas $\left(\mathrm{X}_{1}\right)$, dan 
Profitabilitas $\left(\mathrm{X}_{2}\right)$. Variabel dependent yaitu Return Saham (Y). Selanjutnya dapat dijelaskan definisi operasionalnya dari pengamatan ini sebagai berikut:

\section{Tabel 2}

Definisi Operasional Variabel

\begin{tabular}{|c|c|c|c|c|}
\hline No & Variabel & Definisi & Pengukuran & Sumber \\
\hline 1 & $\begin{array}{l}\text { Return } \\
\text { Saham } \\
\text { (Y) }\end{array}$ & $\begin{array}{l}\text { Merupakan selisih } \\
\text { antara harga saham } \\
\text { tahun sekarang } \\
\text { dengan harga saham } \\
\text { tahun sebelumnya } \\
\text { dibandingkan } \\
\text { dengan harga saham } \\
\text { tahun sebelumnya. }\end{array}$ & $\mathrm{R}_{\mathrm{it}}=\frac{\mathrm{Pit}_{\mathrm{it}}-\mathrm{P}_{\mathrm{it}-1}}{\text { Pit-1}}$ & $\begin{array}{l}\text { Rusliati } \\
\text { dan } \\
\text { Farida, } \\
2010\end{array}$ \\
\hline 2 & $\begin{array}{l}\text { Likuiditas } \\
\left(\mathrm{X}_{1}\right)\end{array}$ & $\begin{array}{l}\text { Current Ratio } \\
\text { merupakan rasio yang } \\
\text { membandingkan } \\
\text { amtara current assets } \\
\text { dibagi dengan current } \\
\text { liabilities. }\end{array}$ & $\begin{array}{l}\text { Current Ratio= } \\
\frac{\text { Current Assets }}{\text { Current Liabilities }} \times 100 \%\end{array}$ & $\begin{array}{l}\text { Fahmi, } \\
2016\end{array}$ \\
\hline 3 & $\begin{array}{c}\text { Profitabilitas } \\
\left(\mathrm{X}_{2}\right)\end{array}$ & $\begin{array}{l}\text { Merupakan rasio } \\
\text { yang } \\
\text { membandingkan } \\
\text { antara laba bersih } \\
\text { setelah pajak dengan } \\
\text { total aset. }\end{array}$ & $\begin{array}{l}R O A= \\
\frac{\text { Laba bersih setelah pajak }}{\text { Total aset }}\end{array}$ & $\begin{array}{c}\text { Melani, } \\
2007\end{array}$ \\
\hline
\end{tabular}

\section{Teknik Analisis Data}

Pengujian hipotesis dilakukan pada penelitian ini dengan tujuan menguji pengaruh likuiditas dan profitabilitas terhadap return saham. Data yang digunakan pada penelitian ini yaitu data panel, yang merupakan gabungan antara data time series dan cross section. Data sampel sebanyak 34 perusahaan diambil dari data unit cross section dan data time series periode 2013-2017.

Analisis statistik deskriptif merupakan metode analisis yang digunakan dalam penelitian ini dan menggunakan Program Eviews (Winarno, 2015) untuk analisis regresi data panel. Persamaan regresi data panel yang digunakan dalam penelitian ini adalah:

$$
\text { RIT }_{i t}=\alpha+\beta_{1} L_{\text {IQ }}+\beta_{2} P_{\text {ROF }}+e
$$

Dimana RIT it merupakan Likuiditas Saham Perusahaan pada waktu t, $\alpha$ merupakan konstanta (intercept), $\beta 1, \beta 2$ merupakan Koefisien Regresi, LIQ ${ }_{\text {it }}$ merupakan Likuiditas perusahaan pada waktu $t, \mathrm{PROF}_{\text {it }}$ merupakan Profitabilitas perusahaan pada waktu t dan e merupakan Standar error.

Pendekatan yang dilakukan dalam analisis regresi data panel yaitu Common Effect Model (CEM), Fixed Effect Model (FEM), Random Effect Model ( REM) (Wulandari, 2017). Ada dua tahapan yang dilakukan untuk menentukan model yang terbaik digunakan antara model tersebut yaitu: Chow Test, untuk menentukan model mana yang terbaik antara Common Effect Model (CEM) dengan Fixed Effect Model (FEM). Hausman Test, dilakukan untuk memilih model mana yang terbaik digunakan antara Fixed effect Model (FEM) dengan Random Effect Model (REM). 
Model regresi yang baik harus menghasilkan estimasi linear tidak bias (Best Linear Unbiased Estimator) (Hadya, Begawati, dan Yusra, 2017).

HASIL DAN PEMBAHASAN

Uji Statistik Deskriptif Variabel

Tabel 3

Hasil Uji Statistik Deskriptif

\begin{tabular}{ccccc}
\hline Variabel & Minimum & Maksimum & Mean & Standar Deviasi \\
\hline Return Saham (RIT) & -0.980000 & 2.570000 & 0.032176 & 0.409497 \\
Likuiditas (LIQ) & 40.31000 & 299.0800 & 153.0898 & 59.35457 \\
Profitabilitas (PROF) & -0.820000 & 71.51000 & 5.772294 & 8.482478 \\
\hline
\end{tabular}

Sumber : data diolah, Eviews 8

Pada Tabel 3 menunjukkan angka-angka deskriptif di masing-masing variabel dengan jumlah observasi sebanyak 170 (seratus tujuh puluh). Uraian hasil dari analisis deskriptif ialah sebagai berikut :

Return saham ialah variabel terikat dengan menggunakan perubahan harga relatif sebagai alat ukur. Nilai minimum sebesar -0.98 berarti bahwa kemampuan perusahaan dalam menghasilkan keuntungan masih rendah sehingga perusahaan lebih sedikit membagikan dividen atas investasi yang dilakukan oleh investor. Adapun perusahaan yang memiliki nilai minimum yaitu PT Sepatu Bata Tbk tahun 2013. Nilai maximum sebesar 2.57 berarti bahwa tingginya kemampuan perusahaan dalam menghasilkan keuntungan sehingga perusahaan lebih banyak membagikan dividen atas investasi yang dilakukan oleh investor. Perusahaan yang memiliki nilai maximum tersebut adalah PT Sekar Laut Tbk pada tahun 2017. Nilai rata-rata (mean) sebesar 0.03. Nilai rata-rata Return saham diatas 0 artinya perusahaan lebih banyak membagikan dividen atas investasi yang dilakukan oleh investor. Nilai standar deviasi Return saham sebesar 0.40 yang menunjukkan penyebaran data yang lebih besar karena nilainya lebih tinggi dari nilai rata-rata (mean).

Variabel independen pada penelitian ini adalah Likuiditas dengan menggunakan CR (Current Ratio) sebagai alat ukur. Nilai minimum CR (Current Ratio) sebesar $40.31 \%$ menunjukkan kemampuan perusahaan untuk membayar kewajiban jangka pendek menggunakan aset lancarnya yang diperoleh pada perusahaan PT Nusantara Inti Corpora Tbk pada tahun 2013. Nilai maximum sebesar $299.08 \%$ menunjukkan kemampuan perusahaan untuk membayar kewajiban jangka pendek menggunakan aset lancarnya yang diperoleh oleh PT Prima Alloy Steel Universal Tbk pada tahun 2017. Nilai rata-rata (mean) sebesar 153.08, artinya dividen yang dibagikan perusahaan lebih banyak atas investasi yang dilakukan oleh investor. Nilai standar deviasi Return saham sebesar 59.35 yang menunjukkan penyebaran data yang lebih besar karena nilainya lebih rendah dari nilai rata-rata (mean).

Selain likuiditas, profitabilitas juga merupakan variabel independen dengan menggunakan ROA (Return On Asset) sebagai alat ukur. Nilai minimum sebesar 0.82 menunjukkan bahwa perusahaan belum mampu menghasilkan laba dengan memanfaatkan aset oleh PT Toba Pulp Lestari Tbk pada tahun 2015. Nilai maximum sebesar 71.51 berarti bahwa PT Sekar laut Tbk pada tahun 2013 mampu menghasilkan laba dengan memanfaatkan asetnya. Nilai rata-rata (mean) ROA (Return On Asset) sebesar 5.77 menunjukkan bahwa perusahaan mampu menghasilkan laba dengan aset. Standar deviasi sebesar 8.48 menunjukkan 
penyebaran data yang lebih besar karena nilainya lebih tinggi dari nilai rata-rata (mean).

\section{Pemilihan Regresi Data Panel}

Dalam data panel untuk pemilihan model yang terbaik dilakukan tahap analisis dengan cara melakukan estimasi model Common Effect (CEM), Fixed Effect (FEM), dan Random Effect (REM). Persamaan regresi likuiditas dengan menggunakan proksi current ratio adalah sebagai berikut:

$$
\mathrm{dRIT}_{\text {it }}=\alpha+\beta 1 \mathrm{LIQ}_{\mathrm{it}}+\beta 2 \mathrm{PROF}_{\mathrm{it}}+\mathrm{e}_{\mathrm{it}}
$$

Persamaan ini menggunakan transformasi diverse pada data return saham di Eviews karena banyaknya data yang outliers (ekstrim) sehingga tereliminasi pada waktu penyeleksian data yang telah dilakukan. Hasil statistik yang diperoleh dalam pengestimasian model CEM, FEM, dan REM adalah sebagai berikut:

\section{Tabel 4}

Tabel Estimasi CEM, FEM, dan REM

\begin{tabular}{ccccccc}
\hline \multirow{2}{*}{ Variabel } & \multicolumn{3}{c}{ Common Effect } & \multicolumn{2}{c}{ Fixed Effect } & \multicolumn{2}{c}{ Random Effect } \\
\cline { 2 - 7 } & t-statistik & prob & t-statistik & prob & t-statistik & prob \\
\hline LIQ & 0.2129 & 0.8317 & 0.1729 & 0.8631 & 0.1935 & 0.8468 \\
PROF & 2.6833 & 0.0082 & 2.7767 & 0.0067 & 2.4400 & 0.0160 \\
\hline
\end{tabular}

Sumber : data diolah, Eviews 8

Tabel 4 menunjukkan hasil estimasi menjelaskan bahwa masing-masing model memiliki nilai signifikansi yang berbeda-beda. Untuk menemukan model mana yang terbaik maka dilakukan analisis lebih lanjut dengan menggunakan Chow Test dan Hausman Test.

Sebelum pengujian lanjutan diestimasi, maka dilakukan uji normalitas terlebih dahulu. Asumsi normalitas hanya terpenuhi pada Random Effect Model (REM). Adapun hasil pengujian sebagai berikut :

\section{Tabel 5}

Hasil Uji Normalitas

\begin{tabular}{cc}
\hline Jarque-Bera & Probability \\
\hline 4.398576 & 0.110882 \\
\hline
\end{tabular}

\section{Sumber :data diolah, Eviews 8}

Berdasarkan tabel diatas, hasil estimasi likuiditas dengan menggunakan indikator current ratio terhadap return saham didapatkan. Nilai probability lebih besar dari alpha $(0.110882>0.05)$ maka dapat dikatakan bahwa residual dalam model penelitian ini telah berdistribusi normal.

Hasil Hausman Test dapat dilihat pada tabel berikut ini:

\section{Tabel 6}




\begin{tabular}{llcc}
\hline Test Summary & $\begin{array}{l}\text { Chi-Sq. } \\
\text { Statistic Chi-Sq. d.f. }\end{array}$ & Prob. \\
\hline \hline Cross-section random & 4.491795 & 2 & 0.1058 \\
\hline Sumber $:$ data diolah, Eviews 8 & &
\end{tabular}

Uji Hausman bertujuan untuk memilih mana model terbaik antara model Fixed Effect Model dan Random Effect Model. Tabel 6 menunjukkan ternyata nilai prob pada Cross-section random lebih besar dari alpha $(\alpha)(0.1058>0.05)$. Dengan demikian, disimpulkan bahwa model yang cocok digunakan dalam regresi data panel adalah Random Effect Model (REM).

\section{Analisis Regresi Data Panel}

Dalam penelitian ini teknik analisis data digunakan untuk mengolah, membahas sampel yang sudah diperoleh dan untuk menilai hipotesis yang diduga. Hasil pengujian penelitian dengan likuiditas menggunakan indikator current ratio dapat dilihat pada tabel berikut:

Tabel 7

Tabel Hasil Estimasi Regresi Data Panel

\begin{tabular}{ccccc}
\hline Variable & Coefficient & Std. Error & t-Statistic & Prob. \\
\hline C & -0.098813 & 0.159210 & -0.620645 & 0.5359 \\
LIQ & 0.000182 & 0.000941 & 0.193595 & 0.8468 \\
PROF & 0.019035 & 0.007801 & 2.440021 & 0.0160 \\
\hline
\end{tabular}

Sumber: data diolah, Eviews 8 berikut:

Persamaan Regresi Data Panel Random Effect Model adalah sebagai

$$
\mathrm{RIT}_{\mathrm{it}}=-0.0988+0.0001 \mathrm{LIQ}_{\mathrm{it}}+0.0190 \mathrm{PROF}_{\mathrm{it}}
$$

Angka pada persamaan regresi data panel didapatkan dari nilai coefficient variabel. Nilai konstanta sebesar -0.0988 ini menjelaskan jika diasumsikan nilai variabel independen bernilai 0 (tidak ada), maka nilai return saham bernilai tetap sebesar -0.0988. Koefisien likuiditas sebesar 0.0001 artinya setiap peningkatan variabel likuiditas sebanyak 1 satuan berarti akan meningkatkan variabel return saham sebesar 0.0001 serta beranggapan variabel lain dalam bentuk konstan. Koefisien profitabilitas sebesar 0.0190 artinya tiap-tiap peningkatan variabel profitabilitas sebanyak 1 satuan berarti akan meningkatkan variabel return saham sebanyak 0.0190 serta beranggapan variabel lain dalam bentuk konstan.

\section{Hasil Pengujian Hipotesis}

Pengujian hipotesis pertama yang terlihat pada Tabel 7 menunjukkan hasil yang bertolak belakang dengan hipotesis yang dibangun. Pengujian menunjukkan nilai t-hitung lebih kecil dari t-tabel $(0.1935<1.9741)$ atau probability lebih besar dari alpha $(0.8468>0.05)$, maka hipotesis pertama $\left(\mathrm{H}_{1}\right)$ dalam penelitian ditolak. Artinya likuiditas tidak berpengaruh terhadap return saham. Untuk variabel profitabilitas menunjukkan nilai t-hitung lebih besar dari t-tabel $(2.4400>1.9741)$ atau probability lebih kecil dari alpha $(0.0160<0.05)$, maka hipotesis kedua $\left(\mathrm{H}_{2}\right)$ 
diterima. Dengan demikian dapat disimpulkan bahwa profitabilitas berpengaruh positif dan signifikan terhadap return saham.

\section{PEMBAHASAN}

\section{Pengaruh Likuiditas terhadap Return Saham}

Berdasarkan hipotesis pertama $\left(\mathrm{H}_{1}\right)$ yang dikemukakan di penelitian ini yaitu, bahwa diduga Likuiditas berpengaruh positif dan signifikan terhadap Return Saham. Sedangkan berdasarkan hasil uji nilai t-hitung untuk variabel likuiditas membuktikan bahwa $\mathrm{H}_{1}$ ditolak. Artinya tidak ada pengaruh yang signifikan antara likuiditas terhadap return saham.

Hal ini dikarenakan bahwa naik turunnya tingkat return saham, tidak dipengaruhi oleh likuiditas. Dalam arti kata, likuiditas tidak berkontribusi terhadap return saham. Secara operasional, return saham tidak ditentukan oleh current asset dan current liabilities yang terdapat dalam likuiditas. Sedangkan likuiditas aset tidak ditentukan oleh harga penutupan saham yang terdapat dalam return saham.

Penelitian ini sejalan dengan Fitriana, Andini dan Oemar, (2016) bahwa tidak berpengaruhnya CR (Current Ratio) terhadap return saham, Karena keyakinan pasar yang mampu dalam memenuhi utang lancarnya, keyakinan investor tersebut disebabkan oleh kuatnya fondasi keuangan pada sektor pertambangan, dan investor tidak terlalu melihat current ratio dalam berinvestasi, sehingga tidak membawa pengaruh pada return saham.

\section{Pengaruh Profitabilitas terhadap Return Saham}

Berdasarkan hipotesis kedua $\left(\mathrm{H}_{2}\right)$ yang dikemukakan dalam penelitian ini yaitu diduga bahwa Profitabilitas berpengaruh positif dan signifikan terhadap Return Saham. Dari hasil uji nilai t-hitung untuk variabel Profitabilitas membuktikan bahwa $\mathrm{H}_{2}$ diterima. Artinya ada pengaruh yang signifikan antara Profitabilitas terhadap Return Saham.

Hal tersebut mengidentifikasikan kalau earning power dari perusahaan menentukan nilai perusahaan. Semakin tinggi earning power dapat meningkatkan efisiensi perputaran aktiva, dan profit margin semakin tinggi pula yang diterima oleh perusahaan. Maka hal tersebut menyebabkan meningkatnya nilai perusahaan dan return saham juga meningkat (Farkhan dan Ika, 2012).

Penelitian Farkhan dan Ika (2012) sejalan dengan penelitan ini yang menunjukkan bahwa, Profitabilitas yang diukur dengan ROA (Return On Asset) berpengaruh positif dan signifikan terhadap Return Saham. Pada penelitannya mengidentifikasikan ternyata untuk memprediksi return saham, investor masih menggunakan return on asset (ROA) sebagai tolak ukur kinerja perusahaan. Dengan demikian, jika return on asset (ROA) suatu perusahaan tinggi, hal ini akan meningkatkan kinerja perusahaan yang baik serta return saham juga akan naik.

\section{SIMPULAN}

Hasil dari penelitian pengaruh Likuiditas (LIQ) dan Profitabilitas (PROF) terhadap Return Saham (RIT) bisa disimpulkan bahwa yang pertama, Likuiditas (LIQ) berpengaruh positif dan tidak signifikan terhadap Return Saham pada perusahaan manufaktur yang terdaftar di Bursa Efek Indonesia periode 2013-2017. Artinya, likuiditas tidak berkontribusi terhadap return saham karena investor kurang memperhatikan CR (Current Ratio) didalam melakukan investasinya dan 
pada akhirnya tidak membawa pengaruh terhadap return saham. Kedua, Profitabilitas (PROF) berpengaruh positif dan signifikan terhadap Return Saham pada perusahaan manufaktur yang terdaftar di Bursa Efek Indonesia periode 20132017. Artinya, jika nilai profit pada perusahaan tinggi, maka kemampuan perusahaan mengoptimalkan asetnya dalam menghasilkan keuntungan juga semakin tinggi.

\section{UCAPAN TERIMA KASIH}

Peneliti mengucapkan terima kasih kepada pihak-pihak yang telah memberikan dukungan dan dorongan dalam melakukan penelitian ini. Penghargaan dan ucapan terima kasih kepada Bursa Efek Indonesia yang telah menyediakan akses ke dalam laporan keuangan tahunan (annual report) perusahaan yang terdaftar di BEI. Sehingga memudahkan peneliti untuk mengumpulkan data sesuai dengan data yang peneliti butuhkan. Penghargaan dan terima kasih juga penulis ucapkan kepada Ketua Sekolah Tinggi Ilmu Ekonomi "Keuangan Perbankan dan Pembangunan", terutama Program Studi Manajemen yang telah memberikan motivasi dan dukungan kepada penulis untuk melakukan penelitian dan penulisan jurnal ini.

\section{DAFTAR PUSTAKA}

Angraini, I., \& Yusra, I. (2019). Pendekatan data panel terhadap return saham: studi empiris pada perusahaan LQ45. INA-Rxiv.

Dewi, A. S. (2016). Pengaruh Ratio Camel terhadap Return Saham pada PT Bank Mandiri Tbk. Pekbis Jurnal, 8(2), 120-129.

Danil, A., \& Yusra, I. (2019). Pengaruh kausal antara ukuran perusahaan, nilai buku dan likuiditas saham di Bursa Efek Indonesia. INA-Rxiv.

Erawati, L., \& Dewi, A. S. (2019). Peran Profitabilitas Sebagai Variabel Interverning Dan Pengaruh Struktur Modal Terhadap Nilai Perusahaan. INARxiv.

Fahmi, I. (2016). Pengantar Manajemen Keuangan. (M. B. . Muslim A. Djalil, S.E., Ak., Ed.). Bandung: ALFABETA, CV.

Farkhan, \& Ika. (2012). Pengaruh Rasio Keuangan Terhadap Return Saham Perusahaan Manufaktur Di Bursa Efek Indonesia. Jurnal Value Added, 9(1), $1-18$.

Fitriana, D., Andini, R., \& Oemar, A. (2016). Pengaruh Likuiditas, Solvabilitas,Profitabilitas, Aktivitas dan Kebijakan Dividen terhadap Return Saham Perusahaan Pertambangan yang Terdaftar pada BEI Periode 20072013. Journal of Accounting, 2(2), 1-16.

Hadya, R. (2013a). Pengaruh Harga dan Risiko Saham Terhadap Likuiditas Saham Pada Perusahaan-Perusahaan Yang Terdaftar Di Bursa Efek Indonesia. Jurnal KBP, 1(2), 208-231. 
Hadya, R. (2014a). Analisis likuiditas, solvabilitas, nilai pasar dan return saham: studi empiris pada perusahaan sektor perbankan yang terdaftar di Bursa Efek Indonesia. Jurnal Riset Manajemen Dan Akuntansi, 3(1), 107-118.

Hadya, R., Begawati, N., \& Yusra, I. (2017). Analisis Efektivitas Pengendalian Biaya, Perputaran Modal Kerja, Dan Rentabilitas Ekonomi Menggunakan Regresi Data Panel. Jurnal Pundi, 1(3), 153-166.

Handayani, F., \& Martha, L. (2019). Hubungan Antara Profitabilitas Dengan Nilai Perusahaan Yang Dimoderasi Oleh Corporate Social Responsibility. INARxiv.

Harahap, R. L., \& Sari, L. F. (2019). Analisis Nilai Perusahaan Berdasakan Profitabilitas, Ukuran Perusahaan, Dan Struktur Modal Di Indonesia. INARxiv.

Kurniawan, T., \& Ghasarma, R. (2009). Pengaruh likuiditas, financial leverage , aktivitas terhadap return saham dengan profitabilitas sebagai variabel mediasi. Jurnal Manajemen Dan Bisnis Sriwijaya, Vol.14 No.

Kurniawan, A., \& Yusra, I. (2019). Apakah profitabilitas dan nilai buku berdampak terhadap return saham?: studi empiris pada perusahaan LQ45. INA-Rxiv.

Martha, L., Sogiroh, N. U., Magdalena, M., \& Susanti, F. (2018). Profitabilitas dan Kebijakan Dividen terhadap Nilai Perusahaan. Jurnal Benefita, 3(2), 227-238.

Mulfita, A., \& Yusra, I. (2019). Analisis regresi data panel terhadap likuiditas saham di Indonesia. INA-Rxiv.

Parwati, R. R. A. D., \& Sudiartha, G. M. (2016). Pengaruh Profitabilitas, Leverage, Likuiditas dan Penilaian Pasar terdahap Return Saham pada Perusahaan Manufaktur. E-Jurnal Manajemen Unud, 5(1), 385-413.

Purnama, S., \& Mayliza, R. (2019). Nilai Perusahaan Di Lihat Dari Aspek Profitabilitas, Ukuran Perusahaan Dengan Struktur Modal Sebagai Variabel Intervening. INA-Rxiv.

Putra, A. D., \& Yusra, I. (2019). Peran profitabilitas dalam memoderasi pengaruh free cash flow terhadap kebijakan dividen di Indonesia. INA-Rxiv.

Putra, I., \& Yusra, I. (2019). Analisis likuiditas saham menggunakan regresi data panel. INA-Rxiv.

Qusibah, V. L., \& Yusra, I. (2019). Profitabilitas , dan Ukuran Perusahaan Sebagai Faktor Penentu Leverage Perusahaan Di Indonesia. Jurnal Pundi, 03(01), 1326. https://doi.org/10.31575/jp.v3i1.125

Rusliati, E., \& Farida, E. N. (2010). Pemecahan Saham terhadap Likuiditas dan Return Saham. Jurnal Bisnis Dan Akuntansi, 12(3), 161-174.

Surya, R. A. S., Agusti, R., \& Asnel, Y. (2010). Analisiis Pengaruh Rasio 
Likuidiitas, Leverage, Aktifitas, dan Profitabilitas Terhadap Return saham pada Perusahaan Consumern Goods yang Tedaftar di BEI. Jurnal Kajian Akuntansi Dan Auditing, 5(1), 1-11.

Sutriani, A. (2014). Pengaruh Profitabilitas, Leverage, dan Likuiditas TerhadapReturn Saham dengan Nilai Tukar Sebagai Variabel Moderasi pada Saham LQ-45. Journal of Business and Banking, 4(1), 67-80.

Tarmizi, R., Soedarsa, H. G., Indrayenti, \& Andrianto, D. (2018). Pengaruh Likuiditas Dan Profitabilitas Terhadap Return Saham. Jurnal Akuntansi Dan Keuangan, 9(1), 1-20.

Wahyuni, I., \& Mayliza, R. (2019). Peran Kebijakan Deviden Dalam Memediasi Pengaruh Profitabilitas Terhadap Nilai Perusahaan. INA-Rxiv.

Winarno, wing wahyu. (2015). Analisis Ekonometrika dan Statistika dengan Eviews (4th ed.). Yogyakarta: Upp Stim Ykpn.

Wira, V. (2012). Pengaruh Kinerja Perusahaan terhadap Likuiditas Saham Menggunakan Trading Turnover. Manajemen Dan Kewirausahaan, 3(2), 97120.

Wulandari, N. (2017). Analisis Faktor-Faktor yang Mempengaruhi Inflasi pada Kota Metropolitan di Indonesia dengan Menggunakan Analisis Data Panel. Sains Matematika Dan Statistika, 3(2), 34-42.

Yulianti, Y. D., \& Yusra, I. (2019). Pergerakan indeks harga saham gabungan sebagai dampak dari variabel makro. INA-Rxiv, 1-11.

Yusra, I. (2019). Composite Indeks Berbasis Variabel Makro: Analisis Kausalitas Data Time Series. Economac, 3(5).

Yusra, I., Hadya, R., Begawati, N., \& Istiqomah, L. (2019). Panel data model estimation: the effect of managerial ownership, capital structure, and company size on corporate value Panel data model estimation : the effect of managerial ownership, capital structure, and company size on corporate value. Journal of Physics: Conference Series, 1175, 1-6. https://doi.org/10.1088/1742$6596 / 1175 / 1 / 012285$

Yusra, I., Hadya, R., \& Fatmasari, R. (2019). The Effect of Retained Earnings on Dividend Policy from the Perspective of Life Cycle. Advances in Social Science, Education and Humanities Research, 203(Iclick 2018), 216-220.

Yusuf, D., \& Yusra, I. (2019). Faktor-faktor yang mempengaruhi struktur modal perusahaan. INA-Rxiv. 